\title{
Suctorian ciliates (Ciliophora, Suctorea) as epibionts of stream-dwelling aquatic beetles (Coleoptera) and water mites (Acari: Hydrachnidia) in the southwestern Palaearctic region
}

\author{
IGOR DOVGAL ${ }^{1} \&$ VLADIMIR PEŠIĆ ${ }^{2}$ \\ ${ }^{1}$ Schmalhausen Institute of Zoology, B. Khmelnitsky str., 15, 01601, Kiev, Ukraine. E-mail: dovgal@izan.kiev.ua \\ ${ }^{2}$ Department of Biology, Faculty of Sciences, University of Montenegro, Cetinjski put b.b., 81000 Podgorica, Montenegro. \\ E-mail:vladopesic@gmail.com
}

\begin{abstract}
Based on original data from recent research, numerous new records of the suctorian species living as epibionts on streamdwelling aquatic beetles (Coleoptera) and water mites (Acari, Hydrachnidia) in the southwestern Palaearctic area are given. The following species are reported for the first time for the national faunas: Setodiscophrya deplanata (Matthes, 1954) (Bosnia and Hercegovina, Montenegro, Serbia, Bulgaria, Turkey), Discophrya helmidis Matthes, 1954 (Montenegro, Turkey), Elatodiscophrya hochi (Matthes, 1954) (Bosnia and Hercegovina, Turkey), Periacineta buckei (Kent, 1881) (Montenegro, Greece), Discophrya lichtensteinii (Claparede \& Lachmann, 1859) (Turkey, Iran). The characteristics of the suctorians as epibionts of stream-dwelling arthropods are briefly outlined.
\end{abstract}

Key words: aquatic beetles, water mites, suctorian ciliates, epibiont, lotic ecosystems

\section{Introduction}

Suctorians (class Suctorea) are a peculiar group of carnivorous or parasitic ciliate (Dovgal 2002), which are poorly known in respect of distribution and species composition living as epibionts on stream-dwelling animals. Many invertebrate groups (i.e., Crustacea, Coleoptera, Acari, etc) living in lotic freshwaters include species that are hosts for epibiotic suctorian ciliates. However, there is considerably lack on the information on suctorian ciliates as epibionts of aquatic beetles and water mites inhabiting lotic ecosystems.

Bameul (1991) reported Periacineta koepelli (Matthes, 1954) and Setodiscophrya deplanata (Matthes, 1954) as epibionts on aquatic beetles of the family Hydraenidae from streams in Spain and France, respectively. Dovgal (1993) recorded, from the Transcarpathian region in the Ukraine, the following suctorian species as epibionts on aquatic beetles: Periacineta molesta (Matthes, 1954) on Hydroporus sp. (Dytiscidae), Discophrya lichtensteinii (Claparede et Lachmann, 1859) (under synonymic name Discophrya cybistericola (Jankowski, 1981) on Agabus sp., (Dytiscidae), Discophrya helmidis Matthes, 1954 on Hydraena sp. (Hydraenidae) and on Hydroporus sp. (Dytiscidae), Discophrya ferrumequinum (Ehrenberg, 1840) (under synonymic name Discophrya speciosa Lachmann, 1859) on Agabus sp. (Dytiscidae) and on Hydrobius fuscipes (Linnaeus, 1758) (Hydrophilidae), Misacineta cybistri (Collin, 1912) on Platambus maculatus Linnaeus, 1758 (Dytiscidae), and on Ilybius fulginosus Gschwendtner, 1934 (Dytiscidae).

There are not many records of suctorians living as epibionts of water mites from the lotic environment. Recently, Dovgal \& Pešić (2007) described a new suctorian species Acineta persiensis Dovgal \& Pešić, 2007 on the water mites Protzia sepasgosariani and P. invalvaris (Acari, Hydrachnidia, Hydryphantidae) from Iran and Montenegro, respectively.

During the survey, conducted by the second author (VP), to explore the diversity of the water mite fauna of the Balkan Peninsula, Turkey and Iran, we observed the presence of suctorian ciliates on many representatives of the 
benthic community from lotic freshwater, belonging to aquatic beetles (Coleoptera) and water mites (Hydrachnidia).

The aim of the present study is to update the records and distribution of suctorian species living as epibionts on aquatic stream-dwelling aquatic beetles and water mites.

\section{Material and methods}

During field work, water mites and aquatic beetles were collected by hand netting, sorted on the spot from other living material and preserved in $75 \%$ ethanol.

For the preparation of slides, the material was stained by Boehmer's hematoxylin and mounted in Canada balsam (see: Dovgal 1996, 2002). The photomicrography was made with the use of digital video camera DC-1200. Permanent slides of infested animals were deposited in the collections of the Department of Fauna and Systematics of Invertebrate Animals of the Schmalhausen Institute of Zoology, National Academy of Sciences, Ukraine.

\section{Results}

\section{Setodiscophrya deplanata (Matthes, 1954)}

(Fig. 1)

New records. BOSNIA AND HERCEGOVINA: W Hercegovina, river Lištica near Široki Brijeg, $43^{\circ} 21^{\prime} N$; 17³7'E, 12.xi.2006, on Hydraena sp. (Coleoptera, Hydraenidae); MONTENEGRO: Podgorica city, river Cijevna near village Dinoša, $42^{\circ} 23^{\prime} 59.48^{\prime \prime} \mathrm{N} ; 1^{\circ} 21^{\prime} 56.26^{\prime \prime} \mathrm{E}, 15.8 .2006$, on Hydraena sp.; Mojkovac town, Dolje Polje village, Ljevok stream, 849 m. a.s.1., $42^{\circ} 59^{\prime} \mathrm{N} ; 1^{\circ} 26^{\prime} \mathrm{E}, 10.8 .2006$, on Hydraena sp.; Podgorica city, spring Ribnička Vrela, 50 m. a.s.l., $42^{\circ} 26^{\prime} 14.10^{\prime \prime} \mathrm{N}$; $19^{\circ} 17^{\prime} 50.62 " \mathrm{E}, 05.8 .2006$, on Hydraena morio; Kolašin town, stream Bistrica, 1122 m. a.s.1., $42^{\circ} 48^{\prime} \mathrm{N}$; $19^{\circ} 27^{\prime} \mathrm{E}, 30.8 .2006$, on Hydraena morio; Rumija Mt., Medjurječka reka-river near Medjurječje, 15.3.2007, on Hydraena sp.; SERBIA: Southern Serbia: Starac Mt., spring near village Gornji Starac, 29.4.2006, on Hydraena sp.; Canyon of the Pčinja river, spring near Monastir Prohor Pčinjski (at the road) 26.4.2006, on Hydraena sp.; BULGARIA: Eastern Rhodopes., Madzharovo town, Malkata Reka stream, 25.6.2006, on Hydraena sp.; TURKEY: Rize Province, Güneysu town, 4058'19"N; 40³6'46"E, upper part of Kangel stream (tributary of Taşli stream) near Kangel village, 18.7.2005, on Hydraena sp.

Diagnosis. Suctorian with disc-shape, flattened, "lenticular" cell with long stalk and clavate tentacles evenly distributed over all the edge of the cell. Macronucleus branched. There are 7-12 contractile vacuoles positioned near the edge of the cell.

Measurements (data combined from Dovgal et al. 2006 and our material from the study area): Cell length 62$106 \mu \mathrm{m}$, width 56-102 $\mu \mathrm{m}$, length of stalk 62-172 $\mu \mathrm{m}$, stalk diameter 4-23 $\mu \mathrm{m}$.

Remarks. New for Bosnia and Hercegovina, Montenegro, Bulgaria and Turkey.

Distribution. Germany: Erlangen vicinity (Matthes 1954c, on Ochthebius minimus); France: Lidoire, Carsacde-Gurson, Dordogne in the Aquitaine region (Bameul 1991, on Hydraena cordata regularis); Ukraine: basin of River Seversky Donets (Dovgal et al. 2006, without host or substrate identification); Russia: lake Podgorskoe, basin of River Volga near Saratov water reservoir (Dovgal et al. 2006, on glass slides); Balkan (present paper, on Hydraena morio and Hydraena sp.), Turkey (present paper, on Hydraena sp.).

\section{Discophrya helmidis Matthes, 1954}

(Fig. 2)

New records. MONTENEGRO: Plav town, Grnčar river near Gusinje, 30.viii.2006, on Hydraena sp.; TURKEY: Rize Province, Sarayköy stream near Sarayköy village (near Rize city, 41 ${ }^{\circ} 1^{\prime} 15^{\prime \prime N} ; 40^{\circ} 31^{\prime} 19^{\prime \prime E}$ ), 270 m. asl., 20.7.2005, on Elmidae (Coleoptera). 

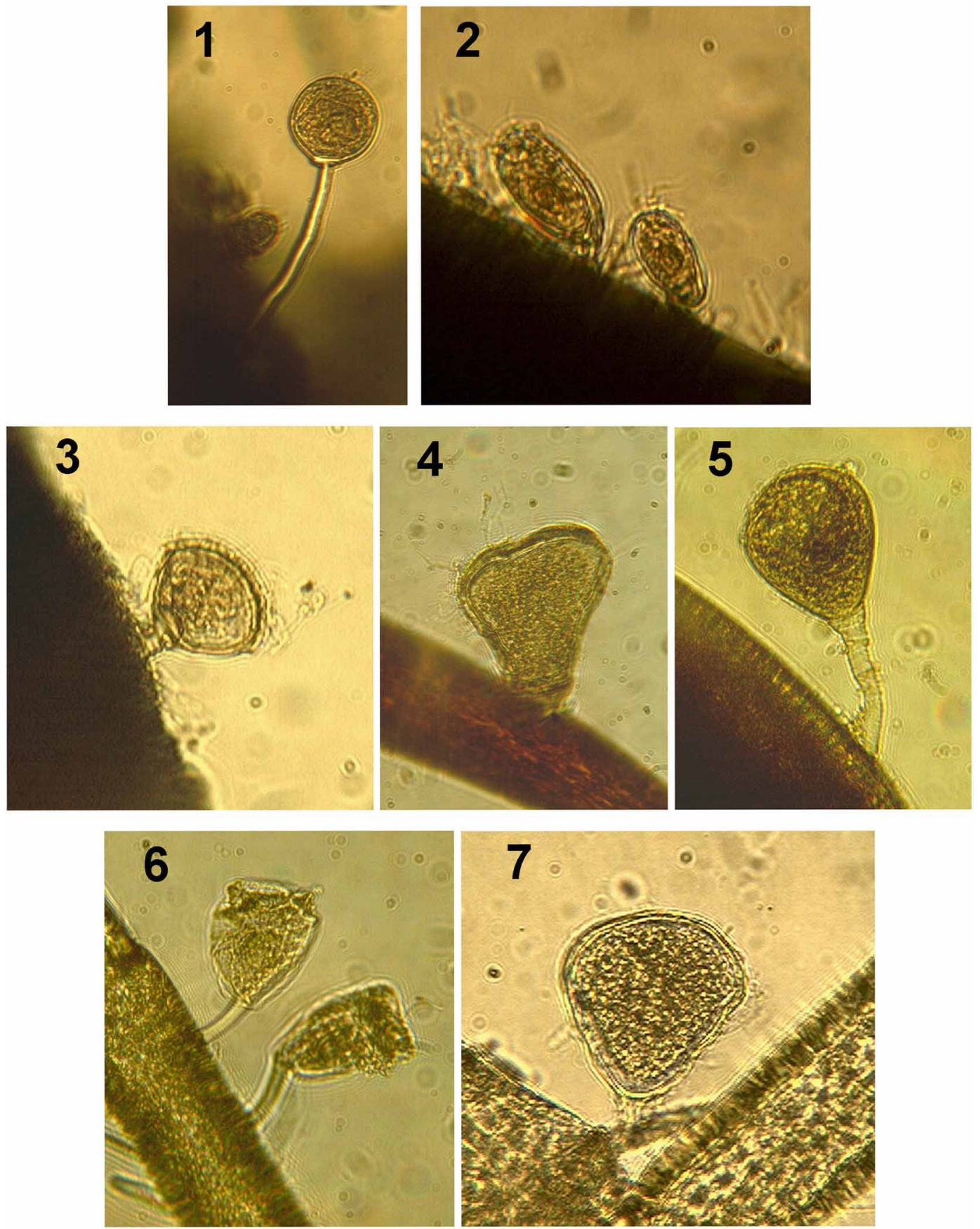

FIGURES 1-7. 1 = Setodiscophrya deplanata (Matthes, 1954), from Hydraena sp. $(\times 640) ; 2$ = Discophrya helmidis Matthes, 1954, from Hydraena sp. (× 640); 3 = Elatodiscophrya hochi (Matthes, 1954), from Hydraena sp. $(\times 640) ; 4=$ Periacineta buckei (Kent, 1881), from Hydraena sp. ( $\times 640)$; 5 = Discophrya lichtensteinii (Claparede \& Lachmann, 1859), from Torrenticola barsica $(\times 640) ; 6=$ Acineta sp. from Torrenticola barsica $(\times 640) ; 7$ = Acineta persiensis Dovgal \& Pešić, 2007, from Protzia sp. $(\times 640)$.

Diagnosis. Suctorian with disc-shape, elongated, flattened cell. Stalk short, cylindrical near the substrate and sharply cup-likely apically flared, with transversal tucks. Clavate tentacles are few in number and evenly distributed over all the edge of the cell. Macronucleus rounded, elongated. There are up to 8 micronuclei. There are $2-4$ apical contractile vacuoles.

Measurements (from Dovgal 1996): Cell length 19-50 $\mu \mathrm{m}$, width 15-42 $\mu \mathrm{m}$, length of stalk 7-30 $\mu \mathrm{m}$.

Remarks. New for Montenegro and Turkey. 
Distribution. Germany (Matthes 1954c, on Hydraena gracilis, H. polita, H. riparia), Ukrainian Carpathians (Dovgal 1993, on Hydraena sp., Hydroporus sp.), Balkan (present paper, on Hydraena sp.), Turkey (present paper, on Elmidae).

\section{Elatodiscophrya hochi (Matthes, 1954)}

(Fig. 3)

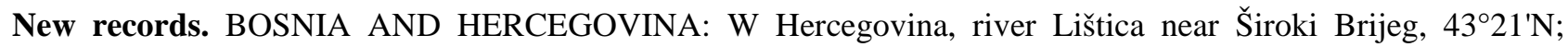
17³7'E, 12.xi.2006, on Hydraena sp.; TURKEY: Artvin Province, Çiftekop stream, a tributary of Çoruh river, 28.7.2005, on Hydraena sp.

Diagnosis. Suctorian with disc-shape, flattened cell. Cell located on a very broad, bed-shaped stalk, in such a way that the cell is covered by widening from one side only. Clavate tentacles are few in number and evenly distributed along the upper edge of the cell and not united in bundles. Macronucleus band-like, sometimes branched. There are 3 or 4 contractile vacuoles positioned near the edge of cell.

Measurements: Cell length 19-57 $\mu \mathrm{m}$ (41-58 $\mu \mathrm{m}$ after Matthes 1954a), width 26-78 $\mu \mathrm{m}$ (61-88 $\mu \mathrm{m}$ after Matthes 1954a), stalk length 8-23 $\mu \mathrm{m}$, length of macronucleus $17-29 \mu \mathrm{m}$.

Remarks. New for Bosnia and Hercegovina and Turkey.

Distribution. Germany (Matthes 1954a, Matthes \& Plachter 1975, on Helophorus flavipes), Balkan (present paper, on Hydraena sp.), Turkey (present paper, on Hydraena sp.).

\section{Periacineta buckei (Kent, 1881)}

(Fig. 4)

New records. MONTENEGRO: Kolašin town, stream Bistrica, 1122 m. a.s.l., 42 $48^{\prime} \mathrm{N} ; 1^{\circ} 27^{\prime} \mathrm{E}, 30.7 .2006$, on Hydraena morio; Berane town, spring near Monastir Djurdjevi Stupovi, $42^{\circ} 51^{\prime} \mathrm{N}$; $19^{\circ} 51^{\prime} \mathrm{E}$, 29.9.2006, on Dryops sp. (Coleoptera, Dryopidae); Mojkovac town, Lepenac stream, 30.ix.2006, on Hydraena sp.; GREECE: Evia Island, the region of Ochi, stream Gefira Dimosaris, downstream between Kalergo and Kallianos vill., 30.6.2007, on Hydraena sp.

Diagnosis. Suctorian with trapeziform, flattened, loricate cell. Lorica smooth, and there is a short stalk. Macronucleus spheroidal or elongate. Clavate tentacles arranged in two apical fascicles. There are from two to four contractile vacuoles.

Measurements: Cell length 16-120 $\mu \mathrm{m}$, width 19-59 $\mu \mathrm{m}$.

Remarks. New for Montenegro and Greece.

Distribution. Widespread species; North America (Nutting 1888 as Acineta compressa, Mariño-Pérez et al. 2011); Japan (Nozawa 1938 as Periacineta tenuis); Europe: Germany (Matthes 1954d), Ukraine (Dovgal 1996), Balkan (present paper); observed on different hosts (Belostoma sp., Lethocerus sp, Ranatra sp., R. linearis, Nepa cinerea, N. rubra, Naucoris cimicoides, Hydraena sp., Argyroneta aquatica, Anacharis sp, Planorbis sp., Planorbarius corneus, Lymnaea stagnalis, Hydrous sp., H. aterrimus, Helophorus sp., Helophorus flavipes, H. fallax, H. asperatus, Hydraena sp., H. morio and Dryops sp.) and inanimate substrates.

\section{Discophrya lichtensteinii (Claparede \& Lachmann, 1859)}

(Fig. 5)

New records. TURKEY: Erzurum Province, Teke stream, 23.7.2006, 3951'50"N; 41 ${ }^{\circ} 13^{\prime} 26^{\prime \prime} \mathrm{E}, 2000$ m. a.s.l., on Protzia sp. (Hydrachnidia, Hydryphantidae); Konya Province, Akşehir, Yayla Stream, 18.4.2004, 38 19'07"N; $31^{\circ} 27^{\prime} 21^{\prime} E, 1060$ m. a.s.l., on Protzia sp.; IRAN: Shanderman (Chafrood) stream 15 km from Masal city, 37²9'N; 49 06 'E, 20.7.2006, on Torrenticola barsica (Hydrachnidia, Torrenticolidae).

Diagnosis. Suctorian ciliate with flattened, disc-shaped or elongate cell. Macronucleus ovoid, centrally located. Contractile clavate tentacles evenly distributed over all the edge of the cell, in some cases only at apical 
part. Stalk cup-shaped or elongate with different lengths, uniformly expanding upwards, with transversal folds. There are from one to three contractile vacuoles in apical part of the cell.

Measurements: Cell length 25-180 $\mu \mathrm{m}$, width 15-160 $\mu \mathrm{m}$, length of stalk 17-192 $\mu \mathrm{m}$.

Remarks. New for Turkey and Iran.

Distribution. Germany (Matthes 1954b, on Dytiscus marginalis, Cybister laterimarginalis, Dytiscus circumflexus, Graphoderes zonatus, G. cinereus, G. bilineatus, Haliplus laminatus, H. flavicollis, H. fluviatilis, H. ruficollis, H. wehnkei, Peltodytes caesus, Brychius elevatus, Graptodytes pictus, Hyphydrus ovatus and Coelambus impressopunctatus), Ukraine (Dovgal 1996, on Agabus sp., Potamonectes sp., Cybister sp., Graphoderes sp., Haliplus sp., Peltodytes sp., Brychius sp., Coelambus impressopunctatus, Potamonectes elegans, Dytiscus circumflexus, Hyphydrus ovatus and H. bicolor; Dovgal 1993 as Discophrya cybistericola, on Agabus sp.), Mexico (Mariño-Pérez et al. 2011, on Ambrysus sp.), Turkey (present paper, on Protzia sp.), Iran (present paper, on Torrenticola barsica).

\section{Acineta sp.}

(Fig. 6)

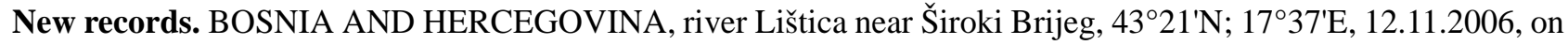
Sperchon gr. denticulatus (Hydrachnidae, Sperchontidae); MONTENEGRO: Rumija Mt., Medjurječka reka-river near Medjurjecje, 15.3.2007, on Partnunia naprintua (Hydrachnidia, Hydryphantidae); Komovi Mt., Štavna, rheohelocrenic spring in forest, $42^{\circ} 42^{\prime} \mathrm{N} ; 1^{\circ} 40^{\prime} \mathrm{E}, 27.5 .2007$, on Partnunia naprintua (Hydrachnidia, Hydryphantidae); TURKEY: Rize province, small stream in lower part of Gaplayam stream near Findikli town $\left(40^{\circ} 52^{\prime} \mathrm{N} ; 39^{\circ} 57^{\prime} \mathrm{E}\right)$, 23.7.2005, on Torrenticola barsica (Torrenticolidae); Turkey, Artvin Province, Hopa stream near Koyuncular village (near Hopa town, $41^{\circ} 24^{\prime} \mathrm{N} ; 41^{\circ} 26^{\prime} \mathrm{E}$ ), ca. 450 m. a.s.l., 28.7.2005, on Torrenticola barsica (Torrenticolidae);

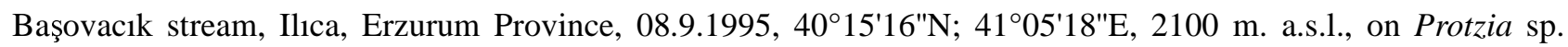
(Hydryphantidae); Erzurum Province, Sirlı stream, Ilıca, 14.9.2006, 40¹4'39"N; 41 ${ }^{\circ} 07^{\prime} 00^{\prime \prime} \mathrm{E}, 2200 \mathrm{~m}$. a.s.1., on Atractides sp. (Hydrachnidia, Hygrobatidae); IRAN: Shanderman (Chafrood) stream $15 \mathrm{~km}$ from Masal city, $37^{\circ} 29^{\prime} \mathrm{N}$; 49 $06^{\circ} \mathrm{E}, 20.7 .2006$, on Torrenticola barsica (Torrenticolidae).

Description. Suctorian ciliate with trapeziform, weakly laterally flattened, loricated cell. There are two fascicles of tentacles located at the apical cell surface. Actinophores absent. Macronucleus rounded, centrally located. Lorica thin-walled, wrinkled. Stalk is solid, slightly apically extended.

Measurements: Cell length 30-33 $\mu \mathrm{m}$, width 23-28 $\mu \mathrm{m}$, length of stalk 16-23 $\mu \mathrm{m}$, diameter of stalk 4-5 $\mu \mathrm{m}$.

Remarks. Acineta Ehrenberg, 1834 is the largest suctorian genus comprising 62 species (Dovgal 2002) and many of these species are morphologically very similar (Curds 1985, Matthes et al. 1988). The examined specimens resemble Acineta tuberosa Ehrenberg, 1834, A. foetida Maupas, 1881 and A. fluviatilis Stokes, 1885, and differ from A. tuberosa by the slightly apically flared stalk and the presence of folds of the lorica (due to this character it differs also from A. fluviatilis), from A. foetida by the absence of characteristic disc-like widening at the tip of the stalk. Furthermore, it is worthy of note that both, Acineta tuberosa and A. foetida are marine species (Dovgal 1996). Since the variability of the above mentioned species needs to be examined in order to clarify the taxonomy, the introduction of a new name at this stage will create more confusion given the present state of knowledge.

\section{Acineta persiensis Dovgal \& Pešić, 2007}

(Fig. 7)

New records. MONTENEGRO: Kolašin town, stream Bistrica, near village Crkvine, 1122 m. a.s.1., 42 ${ }^{\circ} 48^{\prime} \mathrm{N}$; $19^{\circ} 27^{\prime}$ E, 30.ix.2006, on Protzia invalvaris (Hydryphantidae); IRAN: Kerman Province, Jebal Barez Mts., Jiroft city, Temnoieh, Rezvan spring, 15. 6. 2009, on Nilotonia persica (Hydrachnidia, Anisitsiellidae).

Diagnosis. Suctorian ciliate with pear-shaped, laterally flattened, loricated cell. There are two fascicles of tentacles located at the apical cell surface. Actinophores absent. Macronucleus in the form of irregular ellipse, located about centre of the cell. The very thick walls of lorica is characteristic for the species. There is short stalk composed of an adhesive disk. 
Measurements: Cell length 34-58 $\mu \mathrm{m}$, width 34-41 $\mu \mathrm{m}$, length of stalk 5-7 $\mu \mathrm{m}$.

Distribution. Iran (Dovgal \& Pešić 2007, present paper; on Protzia sepasgosariani and Nilotonia persica); Montenegro (Dovgal \& Pešić 2007, present paper; on Protzia invalvaris).

\section{Discussion}

In the lotic habitat, ciliates are exposed to a complex of hydrodynamic factors and most of above listed suctorians have some specific adaptations to hydrodynamic loads on the surface, due to the flow of water (Dovgal \& Kochin 1997, Dovgal 2008) e.g., Periacineta buckei, Acineta persiensis and Acineta sp. have a lorica, Elatodiscophrya hochi bears an extremely flared one-limbed apical part of the stalk which covers the cell, from the side opposite to the host's body surface, while Discophrya lichtensteinii has a stalk of a different length depending on the position on the host's body (Dovgal \& Kochin 1997, Dovgal 2008). However, all the above mentioned suctorian species also occur in stagnant water, and the adaptations listed, in most cases, are because they are living on motile hosts (Dovgal \& Kochin 1997, Dovgal 2008, Mariño-Pérez \& Mayén-Estrada 2009). Thus we can not indicate any specific adaptations to living in lotic habitats. Nevertheless, it can be assumed that the species which have well developed adaptations to hydrodynamic loads, are accordingly better adapted to the conditions in streams with rapid currents and consequently they are more dominant in such habitats.

In this study, Setodiscophrya deplanata (Matthes, 1954) and Periacineta buckei (Kent, 1881) were the most widespread epibionts on aquatic beetles. These two species were found at 10 and 4 sampling sites, respectively. In contrast, Discophrya helmidis Matthes, 1954 and Elatodiscophrya hochi (Matthes, 1954) are found at only two sampling sites, respectively. Setodiscophrya deplanata has been recorded only as an epibiont of members of genus Hydraena.

The most widespread epibiont on water mites was Acineta sp. This species was found at eight sampling sites, while the two other epibionts on water mites, Discophrya lichtensteinii (Claparede \& Lachmann, 1859) and Acineta persiensis Dovgal \& Pešić, 2007, were found at three and two sampling sites, respectively. The epibiotic suctorian ciliates on water mites have not shown specificity to any particular water mite family in the lotic habitat. They have been recorded mainly as epibionts on members of the families Hydryphantidae and Torrenticolidae, which are typical slow moving representatives of the water mites in the lotic habitat. It is worthy of note that Tokophrya wenzeli Matthes \& Stiebler, 1970, the first described epibiontic suctorian ciliate from water mites, was not observed in our study, and it seems likely that this species is a characteristic epibiont of freshwater mites from lentic water (Dovgal et al. in press).

Our study reveals interesting patterns for some species, for example, records of Discophrya lichtensteinii on water mites, which are not characteristic for these suctorians (most records coming from aquatic beetles, see Matthes et al. 1988), indicating that this suctorian species, in the lotic habitat, probably prefers water mite hosts. On the other hand, numerous records of such extremely rare species as Setodiscophrya deplanata, indicate that this suctorian species probably prefers conditions characteristic of the lotic habitat.

\section{Acknowledgements}

We thank Dr Richard Baker (UK) for his comments and for checking the English. We are thankful to Dr AndréDenis G. Wright (Burlington), and three anonymous referees for their careful work and valuable comments.

\section{References}

Curds, C.R. (1985) A revision of Suctoria (Ciliophora, Kinetofragminofora) 1. Acineta and its morphological relatives. Bulletin of the British Museum (Natural History) Zoology, 48 (2), 75-129.

Bameul, F. (1991) Note on two phoretic Discophrya (Protozoa: Suctoria) found on Hydraena (Insecta: Coleoptera: Hydraenidae) in Spain and France. Bulletin de la Societe Linneenne de Bordeaux, 19 (2), 97-102.

Dovgal, I.V. (1993) Tentaculous infusoria (Ciliophora, Suctoria) of the East Carpathian mountains and surrounding areas. In: Proceedings of the East Carpathian fauna: its present state and prospects of preservation, Kiev, pp. 267-270. 
Dovgal, I.V. (1996) Keys for identification of tentaculous infusoria (Ciliophora, Suctoria) of the Ukrainian fauna. Vestnik zoologii, Supplement, 2, 1-42.

Dovgal, I.V. (2002) Evolution, phylogeny and classification of Suctorea (Ciliophora). Protistology, 2 (4), 194-270.

Dovgal, I.V. (2008) Micro-spatial structure of periphytonic communities: determinal factors. Natura Montenegrina, 7, 117123.

Dovgal, I.V. \& Kochin, V.A. (1997) Fluid boundary layer as an adaptive zone for sessile protists. Journal obschej Biologii, 58 (2), 67-74.

Dovgal, I.V., Zharikov, V.V. \& Bykova, S.V. (2006) The systematic revision of the genus Setodiscophrya (Ciliophora, Suctorea). Vestnik zoologii, 40 (6), 497-504.

Dovgal, I.V. \& Pešić, V. (2007) Acineta persiensis sp.n. (Ciliophora, Suctorea) - a new freshwater suctorian species from the water mites of genus Protzia (Acari, Hydrachnidia). Vestnik zoologii, 41 (2), 165-167.

Dovgal, I.V., Zawal, A. \& Pešić, V. New finds of Tokophrya wenzeli (Ciliophora, Suctorea) the commensal of water mites (Acari, Hydrachnidia) and redescription of the species. Vestnik zoologii (in press).

Mariño-Pérez, R. \& Mayén-Estrada, R. (2009) Epibiotic relationship between two species of suctorians (Protozoa: Suctoria) and Corisella edulis (Heteroptera: Corixidae). Aquatic Insects, 31 (3), 235-246.

Mariño-Pérez, R., Dovgal, I. \& Mayén-Estrada, R. (2011) New records of suctorians (Ciliophora: Suctoria) as epibionts of aquatic true bugs (Hemiptera: Prosorrhyncha, Nepomorpha) from two regions: Mexico and Eastern Europe. Zootaxa, 2798, 46-80.

Matthes D. (1954a) Suktorienstudien I. Beitrag zur Kenntnis der Gattung Discophrya Lachmann. Archiv für Protistenkunde, 99 (4), 187-226.

Matthes, D. (1954b) Suktorienstudien III. Discophrya lichtensteinii (Claparede \& Lachmann 1858) Collin 1912, ein an Halipliden und Dytisciden gebundenes Suktor. Zoologischer Anzeiger, 152 (9-10), 252-262.

Matthes, D. (1954c) Suktorienstudien IV. Neue obligatorisch symphoriont mit Wasserkafern vergesellschaftete DiscophryaArten. Zoologischer Anzeiger, 153 (3-4), 76-88.

Matthes, D. (1954d) Suktorienstudien VII. Discophrya buckei (Kent), eine formenreiche Art der Linguifera-Gruppe. Zoologischer Anzeiger, 153 (9-10), 242-250.

Matthes, D. \& Plachter, H. (1975) Suctorien der Gattung Discophrya als Symphorionten von Helophorus und Ochthebius als Traeger symbiontischer Bakterien. Protistologica, 11 (1), 5-14.

Matthes, D., Guhl, W. \& Haider, G. (1988) Suctoria und Urceolariidae (Peritrichia). Protozoenfauna Band 7/1. Gustav Fischer Verlag, Stuttgart, 309 pp.

Nozawa, K. (1938) Some new freshwater Suctoria. Annotationes Zoologicae Japonenses, 17 (3), 247-259.

Nutting, C. (1888) Description of supposed new species of Acinetan. American Naturalist, 22, 13-17. 